\title{
REVIEW
}

\section{PELAGIUS' COMMENTARY ON THE PAULINE EPISTLES AND ITS HISTORY.}

Pelagius in Irland: Texte und Untersuchungen zur patristischen Litteratur. Von Heinrich Zımmer. Berlin (Weidmannsche Buchhandlung), $\mathbf{1}$ gor.

THE merits of this book are many and solid: its demerits lie on the surface, and may be dismissed in two or three sentences. Its contents do not correspond with its title: it is misleading to call your book 'Pelagius in Ireland' when you are going to write not so much about Pelagius as about his Commentary on St. Paul's Epistles, and not so much about Ireland as about Irish scholars and manuscripts on the continent. Its arrangement, partly no doubt owing to the accumulation of new material while it was in progress, is more faulty and confusing than would have been thought possible. And it is disfigured from time to time by expressions of opinion, intended to exalt Celts over Romans in general, and Pelagius as a Celt over his Roman contemporaries in particular, of which the following instance may suffice-the italics are my own-' Der Herrschaft des weltlichen Rom, das mehr als 300 Jahre die irische Freiheit aus nachster Nahe bedrohte, war Irland glücklich entgangen' (p. 224 n.). It is a pity that Dr. Zimmer does not realise that it is possible to sympathise with Pelagius and yet not to believe him wholly right, possible to dislike Jerome's controversial methods without admitting that the cause on behalf of which they were exercised was necessarily bad. But having said so much by way of criticism, it is necessary to add at once that the book is one of first-rate importance, that if it is troublesome to master it is well worth the trouble, and that indeed it may be pronounced indispensable to all serious students of the history of patristic exegesis. I cannot do better in this review than try to render access to the book easier to Englısh readers by putting Dr. Zimmer's facts and arguments before them in my own words and in my own arrangement. I propose then first to examine the allusions in early Latin writers to commentaries on St. Paul's Epistles; then to compare with these allusions the material hitherto extant in print; lastly to bring into account the additional evidence from Irish sources collected in this volume, and so to throw into clear relief the value of Dr. Zimmer's 
contribution to the study of the subject : with this proviso only, that on one subordinate but interesting problem I shall venture to dispute his conclusion and to offer a solution of my own.

I. Of commentaries of Pelagius clear mention is made by both St. Augustine and Marius Mercator. Mercator cites them as 'in apostolum Paulum commentarios,' and tells us that they were written before the sack of Rome (A.D. 410): Augustine calls them 'in Pauli apostoli epistulas expositiones breuissimas,' and in one place quotes them in a way which suggests that though their author was generally known they did not formally bear his name-'sunt quaedam expositiones epistulae Pauli quae scribitur ad Romanos, quae ipsius Pelagii esse dicuntur '? There was of course no necessary reason why annotated editions of parts of Scripture should bear the annotator's name, until such explanations multiplied so far as to make it convenient to distinguish one set of them from another.

Augustine further cites an interpretation of Romans $\mathbf{v}$ i 2 given by 'sanctus Hilarius 2,' meaning no doubt St. Hilary of Poitiers. There is nothing indeed in his words to shew that he is quoting from a continuous commentary, but we shall see later on that this is in fact the case.

But the locus classicus on this early Western exegetical literature, so far at least as it was known in the sixth century, is the eighth chapter of the de Institutione diuinarum litterarum, where Cassiodorus gives the inmates of his monastery of Vivarium in S. Italy a description of all the complete Latin commentaries on the Pauline Epistles, five in number, of which he knew or had heard ${ }^{3}$. (1) The first of these was also obviously the most important. The merits of its concise and acute method of statement were universally recognised, and Cassiodorus himself was not insensible to them. But careful study of it had shewn him that the 'poison of Pelagian error' was contained in it-which alone was enough to prove that it was not the work, as was sometimes asserted, of Pope Gelasius-and he had therefore undertaken the task of re-writing the whole of the section on the Roman Epistle, leaving his disciples to continue the same process for the other Epistles 4. (2) The second commentary, likewise anonymous, was orthodox, and treated the thirteen epistles 'non ignorabili adnotatione.' (3) The third, like the first, is said to have been 'very brief' in its notes: some attributed it to

1 Pelagius in Irland, pp. 13, 15 n.

ib. p. 119 .

3 s. pp. 201-203.

- It is not, I think, necessary to conclude from the words of his later book de orthographra that the disciples' part of the business was still unfulfilled: 'expositionem epistulae quae scribitur ad Romanos unde Pelagranae baereseos prauitates amour, quod etıam in reliquo commentario facere sequentes admonui ' (Zimmer, p. 210 
St. Jerome. From the fact that Cassiodorus uses the word 'dicitur' in relation not only to the Hieronymian authorship but to the brevity of the notes, one would conclude that, though he might no doubt have seen the book, he did not lay claim to much first-hand acquaintance with it. (4) The fourth commentary was only a cento from the works of St. Augustine, put together by an abbot Peter of Tripoli, and may for our purpose be left out of account. (5) The fifth and last was one which St. Ambrose was said to have left behind him, 'suauissima expositione completum': but Cassiodorus had never yet managed to come across a copy.

Cassiodorus therefore supposed himself to know (beyond the work of abbot Peter) of four different commentaries. But he had only read two of them, and one he had never seen at all, so that the possibility must remain open that the third and last were not wholly independent of the other two. It is at least certain that neither the 'Jerome' nor the 'Ambrose' commentary belonged in reality to its putative author: for if either of these two fathers had left a continuous commentary we should certainly have had other knowledge of it.

II. If we now turn to the early Latin commentaries on the whole series of Pauline epistles which are extant in print, and take the sixth century, the age of Cassiodorus, as our terminus ad quem, we find no more than three-Ambrosiaster or Pseudo-Ambrose, Pseudo-Jerome, and Pseudo-Primasius. These commentaries were originally published, no doubt on MS authority of some sort or other, under the name of Ambrose Jerome and Primasius respectively, and can still be read only in the editions, or appendices to the editions, of these Fathers : but, as the prefix implies, the attribution is now in each case recognised as incorrect.

With regard to the Ambrosiaster, internal evidence shews that he wrote under the pontificate of Damasus, and no doubt at Rome: 'cum totus mundus Dei sit, ecclesia tamen domus eius dicatur, cuius hodie rector est Damasus,' is his comment on 1 Tim. ii 15. The date warrants the clain that this is the earliest complete Pauline commentary in any language ; but the personality of the author is quite uncertain. Ambrose, indeed, is out of the question; though as all the probabilities are in favour of identifying the 'Ambrose' commentary of Cassiodorus with our Ambrosiaster, the ascription must be as old as the sixth century. Still earlier is the ascription to 'Hilary,' for the interpretation of Rom. $\mathrm{V} 12$ which Augustine quotes (as has already been mentioned) from 'sanctus Hilarius,' actually comes from our Ambrosiaster: it was under the name Hilary also, as Dr. Zimmer shews, that the commentary was known and used in Ireland. Either then the commentator really was an otherwise unknown Roman Christian Hilary, who was confounded 
at least by Augustine with his more illustrious namesake-and this is Dr. Zimmer's view ${ }^{1}$-or the name Hilary got attached to the work exactly like the name Ambrose, as that of a great contemporary saint and writer, no other person being meant from the beginning than St. Hilary of Poitiers. If the latter view is correct, the work must have been published anonymously, and the ground remains free for Dom Morin's ingenious and attractive theory that the true author was the converted Jew Isaac, who played a not unimportant part in the Roman Church politics of Damasus' day and afterwards relapsed into Judaism.

The commentary of Pseudo-Jerome on the thirteen Epistles of St. Paul first appeared in Amorbach's edition of Jerome (Basel, 1516 ), and owed its place there to the fact that a 'very ancient' MS of it, Gotthicis litteris exaratus, gave that father as its author. Of the next editors of Jerome, Erasmus rightly saw that the commentary was pseudonymous -if only because of the contrast of its concise and pithy style with Jerome's diffuse exposition-and Marius Victorius that it was Pelagian : but it was Garnier, the seventeenth-century editor of Mercator, who first developed what may be called the accepted view, that we possess in it the revision which (as we have seen) Cassiodorus undertook of the commentary of Pelagius '. That Pseudo-Jerome is not unconnected with Pelagius is made certain by the single fact that most of Augustine's and Mercator's citations from Pelagius are present in Pseudo-Jerome: just as the absence of one or two of their citations proves that PseudoJerome is not Pelagius pure and simple, but a revised form of it. What more obvious then than to see in Pseudo-Jerome Cassiodorus' edition of Pelagius? Yet Dr. Zimmer objects with reason that it is impossible that Cassiodorus, himself a strict Augustinian, should have retained, after his 'careful purging' of the commentary on Romans, as many as six of the passages to which Augustine and Mercator had taken special exception on doctrinal grounds: and he proposes the much more satisfactory alternative of identifying our Pseudo-Jerome with the third commentary on Cassiodorus' list - the one 'which by some is said to contain very brief annotations by blessed Jeromes.' The perfunctory character of Cassiodorus' acquaintance with this commentary would sufficiently explain why its Pelagian tinge had escaped him. The 'Jerome' of Amorbach's MS will then be the same as the 'Jerome' of Cassiodorus.

The third of our printed commentaries is that of which the editio princeps was published by Gagney in 1537 under the name of Primasius. No doubt the ascription rested on some MS or MSS : but neither ancient evidence nor internal probability points to the authorship of the celebrated

1 Pelagius in Irland, pp. 117-120.

36. pp. 201, 206 .

26. pp. $14-16$. 
African writer of the sixth century, Primasius of Hadrumetum. On the other hand the connexion of this commentary with that of Pseudo-Jerome, in all respects save where anti-Pelagian orthodoxy called for alteration, is, as Dr. Zimmer was the first to notice, extremely close: e.g. on the Epistle to Philemon Pseudo-Primasius has nineteen notes, PseudoJerome twenty-one, and sixteen of these are verbally identical, or nearly so, in the two commentators: it is in fact only in the commentary on Romans that the divergence is at all marked. Here then we appear to have a second revision, made apparently from doctrinal motives, of the lost commentaries of Pelagius: and in this case we have a terminus $a$ quo for the date in A.D. 450 , since the words 'death reigned until Moses' are illustrated by the parallel phrase 'fuerunt Hunni usque ad Attilam '.'

III. If we now compare the list of Cassiodorus with the commentaries just described, we shall find that we have already identified his last or Ambrose commentary with our Ambrosiaster, and his third or Jerome commentary with our Pseudo-Jerome. There remain his first and second : and if we grant Dr. Zimmer's premiss, that books known to the sixth century are more likely than not to have survived till the twentieth, we shall probably not hesitate to see in the second commentary-doctrinally and exegetically sound, and fuller than the first or third-another reference to the Ambrosiaster: Cassiodorus, of course, would naturally not suspect that the Ambrose for which he had vainly sought might turn out to be a commentary which, without name of author, had been all the time in his hands ${ }^{2}$. But what of that first commentary-popular, brief, subtle, but Pelagianizing-of which Cassiodorus commenced, but did not himself complete, the revision? Was it, as Garnier and most scholars since his time have thought, the original (though of course anonymous) Pelagius? or is Dr. Zimmer right that it was our Pseudo-Primasius, and that nothing of the whole Pauline library of Cassiodorus has disappeared, except his own revision of the commentary on the Romans ${ }^{3}$ ?

The key to the explanation of the mutual relation of the three revisions of Pelagius' commentary by Pseudo-Jerome, Pseudo-Primasius, and Cassiodorus, is naturally to be sought in the recovery of their lost original. To have achieved something like this recovery, and to have paved the way for a complete edition of the text of Pelagius, is the signal merit of Dr. Zimmer.

Pelagius was of British, perhaps of specifically Irish, origin. How powerful an influence his teaching had in England we know from the visit of Germanus of Auxerre and Lupus of Troyes in 429 : in Ireland its influence may well have been equally great, and the Irish Church

\footnotetext{
${ }^{1}$ Pelagius in Irland, pp. 121-123, 135.

2 เ. p. 207.

3. b. $20_{4}$ sqq.
} 
had no close relations with the continental Churches to counteract it. The barbarian invasions soon interposed a heathen barrier between Christian Ireland and Christian Europe; and after the mission of Palladius in $43 \mathrm{I}$ direct contact ceased for some hundred and fifty years. That Pelagianism, however, was alıve in Ireland at the end of this perrod of separation is established by the direct evidence of a letter of Pope John IV in A.D. 640, in which the North Irish Church is blamed not only for its schismatic Easter reckoning but for its revived Pelagianism ${ }^{1}$. And 1 , in connexion with this, we bear in mind the high degree of culture to which Irish monasteries attained during that long isolation, and the careful preservation and study of the older Christian literature therein implied, we shall naturally look to Ireland as the quarter where the writings of Pelagius were most likely to have continued in use and to have escaped the suppression of their author's name. It is in this direction that Dr. Zimmer's researches have been so fruitful of results. The 'Irish' collection of canons, about 700 A.D., twice quotes the authority of 'Pelagius?' The Book of Armagh, A. D. 807, has several longer prologues at the head of the Paulıne Epistles, and briefer summaries to each individual epistle: of the former, two are entitled respectively 'prologus Pilagi in omnes aepistolas' and 'prologus Pilagii in aepistolam ad Romanos,' while of the latter ten bear the superscription 'algumentum Pilagii ${ }^{3}$.' When the tide set from Ireland to the contınent, the Irısh missionaries took their Pelagius with them. A Wurzburg MS of the Epistles (cod. Wirceb. mp. th. f. I2), written about 800 A.D., is equipped with a marginal and interlinear commentary, part Latin, part Irish : the Irish glosses were edited by Dr. Zimmer himself twenty years back, but the Latin, to which he has now turned his attention, are historically of no less interest. Much is anonymous in this Catena, but seven authors are cited by name-Origen on the Romans (Ori.) twenty times; Ambrosiaster ( $\mathrm{Hel}$. or $\mathrm{Hll}$., i.e. Hilary) twenty-nine times; Jerome, mainly from his four commentaries on Pauline epistles-Galatians Ephesians Titus and Philemon-(Hir.) I 16 times; Augustine (Aug. or $A g$.) nine times; Gregory the Great $(G g$. $)$ fifty tumes ; Isidore $(I s$.$) five$ tımes; but Pelagius $(P l$.$) no less than 949$ tımes ${ }^{4}$. The Collectanea ad omnes b. Pauli epistolas of Sedulius Scotus, an Irishman who taught at Liège Cologne and Metz about the middle of the ninth century, quote by name, an exposition of Pelagius-' aliter secundum Pil.'-on Rom. i $17^{5}$. The ninth and tenth century catalogues of three libraries on the

\footnotetext{
1 Pelagius in Irland, pp. 22-24.

2 ib. pp. $24,25$.

3b. pp. 25-39.
}

' b. pp. 39-117. Of these 949 citations from 'Pelagius,' 840 are found in Ps.-Jerome: the figures presumably measure the extent of Pseudo-Jerome's revision.

เ6. pp. 112, 113. 
line of Irish travel include Pelagius' commentary: 'expositio Pelagii super xiii epistolas Pauli' at St. Ricquier in Picardy, 'Pelagii super omnes epistolas Pauli in uno codice' at Lorsch on the Rhine, 'expositio Pelagii super omnes epistolas Pauli in vol. I' at St. Gall ' . And as late as 1079 A.D. Marianus Scotus, founder of an Irish monastery at Regensburg, wrote there 'for the use of his brethren from foreign parts' an annotated copy of the Epistles, now at Vienna (cod. Vindob. 1247), in which the name of Pelagius is still attached to the general prologuethough that of Jerome has been written over it-and to 203 explanations in the body of the text ${ }^{2}$.

That the commentary of Pelagius was popular in Irish circles for a long period during which it was quite unknown (under that name) elsewhere, is thus abundantly clear: and the material to be extracted from the Wurzburg and Vienna MSS for the criticism of the 'continental' revisions by Pseudo-Jerome and Pseudo-Primasius, and therewith for the restoration of the true text of Pelagius, is very considerable. Much of the first half of the book under review is occupied with elaborate preparations for this task-a task which has, however, been rendered in part easier and in part unnecessary by a happy discovery of Dr. Zimmer's, made after his earlier chapters had been written. For the Pelagius MS catalogued at St. Gall somewhere before A. D. 900, which Dr. Zimmer had at first sought in vain, turns out to be after all still extant as 'codex Sangallensis 73, Glossae incerti auctoris,' the first leaf, and with it the author's name and prologue, having been lost between the ninth century and the nineteenth. That in this now anonymous MS we possess some form of the Pelagius commentary, the most cursory examination of its matter in comparison with Pseudo-Primasius, or still better with PseudoJerome, is enough to shew : that it is the Irish form becomes certain from its repeated agreement in textual details with the Irish authorities against both Pseudo-Primasius and Pseudo-Jerome: and finally that it is a doctrinally unadulterated form is shewn by its retaining every single passage criticised by Augustine and Mercator, including even what was omitted by Pseudo-Jerome.

Yet the new discovery does not enable us to dispense-far from itwith the older material. In the St. Gall MS, besides an unusually large proportion of omissions from careless copying, and besides the accidental loss of two leaves, there are evidences at two separate points of the hand of an editor: in the First Epistle to the Corinthians section-headings are introduced, and alternative explanations are as a rule suppressed; and in the Epıstles to the Galatians, Ephesians, Philemon and Titus, on which St. Jerome wrote, much has been interpolated into the commentaries of Pelagius from the commentaries of his great opponent ${ }^{3}$. It is
1 Pelagius in Irland, pp. 156-158.
?b. pp. 137-155.
sib. pp. 242-271. 
indeed not improbable that all the 'Irish' witnesses give a text which has suffered contamination-literary, not doctrinal-from Hieronymian sources: so that for these four epistles special caution must be used in admitting, as part of the ultimate Pelagius text, anything which is not guaranteed by one or other of the two continental authorities, PseudoJerome or Pseudo-Primasius.

About the relation of the Pelagius commentary to the epistle to the Hebrews a word must be said separately. When Pelagius wrote, Western and Roman opinion on the subject of that epistle was just coming into line with the rest of the Christian world. Ambrosiaster indeed had not included the epistle in his commentary : but Damasus' Council of $3^{82}$ A D. had reckoned it as Pauline, and this was also the line taken by Pelagius himself in his general prologue to the epistles. There is therefore every ground to expect that Pelagius commented on all fourteen epistles: and in fact two authorities for the Pelagius text, the St. Gall MS and Pseudo-Primasius, conclude with an exposition of the Hebrews. On the other hand Pseudo-Jerome has no commentary on this epistle, the Wurzburg and Vienna MSS have no Pelagius citations on this epistle, while the commentaries of St. Gall and PseudoPrimasius differ here so much from one another that they cannot be regarded as two recensions of one original. Moreover Cassiodorus distinctly speaks of his first or Pelagianizing commentary as a commentary on thirteen epistles of St. Paul : and it is universally agreed among scholars that this commentary was either the actual Pelagius itself or at least a recension of it. We seem forced therefore to the conclusion that, whatever his reason, Pelagius did not in fact extend his exposition to the epistle to the Hebrews ${ }^{1}$.

It is obvious then that large deductions must be made from any claim of the St. Gall MS to be a faithful reproduction of the original Pelagius : and Dr. Zimmer was perhaps wise in confining himself to a full collation of the new manuscript with the printed (Migne) text of Pseudo-Jerome, the commentary on Romans $i$ and $v$ I 2-2I, and on Hebrews, being alone given in extenso ${ }^{2}$. But though he has thus exhausted the materials at present available on the side of the Irish tradition, the recovery of the original Pelagius can only be accomplished when the continental tradition of Pseudo-Jerome and Pseudo-Primasius has been critically edited from MSS. The two latter commentaries, like that of Ambrosiaster, though they have been known ever since the revival of letters, have suffered from the neglect which for generations has been the fate of every document to which the brand of spuriousness had been once attached. Is it too much to hope that as Vienna has its corpus of Latin Fathers, and Berlin its corpus of ante-Nicene Greek Fathers, so our English

\footnotetext{
1 Pelagius in Irland, pp. 1 $7^{8-200,} 27$ 1-276.

ib. pp. $280-44^{8}$.
} 
Universities should undertake the editing of the exegetical writings of the Fathers on the New Testament? It is in this direction that our special strength seems to lie : at least it would be difficult to name any other department of patristic study in which the last sixty years of English scholarship has produced an output of good work equal to Cramer's Catena, Field's Chrysostom on St. Mattheze and on St. Paul, P. E. Pusey's Cyril on St. John, Swete's Theodore on St. Paul, Brooke's Origen on St. John, and Gregg's Origen on the Ephesians just completed in this Journal. Pelagius and Ambrosiaster would be in good company.

I venture to return, before concluding, to one literary question, the answer to which was left open in the course of this review for the reason that I wished to keep my exposition of Dr. Zimmer's argument free from any premature expression of dissent. What was the nature of the 'Pelagianizing' commentary which Cassiodorus began to re-write? Was it, as Garnier held, the real though anonymous Pelagius? Or was it, as Dr. Zimmer believes, the commentary now known as PseudoPrimasius? The difficulties of Garnier's view appear to be far less than those of Dr. Zimmer's. The latter's main argument against Garnier is that the genuine Pelagius commentary could not possibly have been attributed to Gelasius within half a century after that pope's death, seeing that even if he was not the author of the so-called Gelasian decree de libris non recipiendis-among the libri non recipiendi are included in the lump all the writings of Pelagius--he had at any rate certainly written against Pelagianism. No doubt the confusion is strange : but is it any more strange than the fact that an edition of Pelagius' commentary, with no essential modification of the doctrinal standpoint, passed-and passed already, it would seem, in Cassiodorus' timeunder no less a name than Jerome? Possibly the similarity of the names Gelasius and Pelagius may have lent assistance to the error: certainly it would be hard to set limits to the freaks or the audacity of pseudonymous ascription. But in any case, and however matters stand for Garnier's identification with Pelagius, Dr. Zımmer's identıfication with Pseudo-Primasius seems to me liable to a much more serious objection. For Pseudo-Primasius is definitely and consciously antiPelagian throughout: 'hoc contra Pelagianos facit,' 'hoc contra Pelagium facit,' 'contra abruptum Pelagianae impietatis errorem,' 'non sicut Pelagiani de hoc loco sentiunt,' 'ubi est superbia Pelagiana?'-these are the phrases which he engrafts on to the Pelagian stock, and how then could Cassiodorus speak of 'Pelagiani erroris uenena'? Moreover, it is specially in the commentary on Romans that Pseudo-Primasius has found it necessary to re-write Pelagius : it would surely be curious that 
it should be specially in the commentary on the same epistle that Cassiodorus found it necessary to re-write Pseudo-Primasius!

Of the two views then which have been propounded as to the character of the 'Pelagianizing' commentary, we shall more easily accept that which identifies it with Pelagius' own work : but we shall be tempted to ask further why, when all the other contents of Cassiodorus' Pauline library have been thus identified with extant documents, Cassiodorus' own revision of this commentary should be left out in the cold. Neither Garnier nor Zimmer appears to offer any suggestion here : and yet Cassiodorus was no obscure writer, whose works would perish easily and leave no trace behind. His revision might indeed have circulated anonymously-being neither Pelagius proper nor Cassiodorus properand so even pseudonymously, but it is difficult to think it could have wholly disappeared. And if Dr. Zimmer's identification of PseudoPrimasius with the 'Pelagianizing' commentary is wrong, is not the field left open for the identification of Pseudo-Primasius with Cassiodonis' missing revision? Pseudo-Primasius is based on Pelagius: if Garnier and the scholars who have followed him are right, Cassiodorus revised Pelagius. Pseudo-Primasius is an anti-Pelagian edition of Pelagius : so was that of Cassiodorus. Pseudo-Primasius has revised his original more on the doctrinal than on the linguistic side, more in the epistle to the Romans than in the other epistles': Cassiodorus 'in order to remove far the error of heresy' purged the epistle to the Romans with all the curiositas that he could, leaving the rest of the revision to his pupils, whose work will doubtless have been much more perfunctory than their master's. Pseudo-Primasius adds to the genuine Pelagius on the thirteen epistles a commentary on the Hebrews, which depends on Chrysostom's Homilies ${ }^{2}$ : but it was Cassiodorus who, in order to provide a commentary on an epistle which both Ambrosiaster and Pelagius had neglected, caused a certain Mutianus to translate these Homilies of Chrysostom into Latin ${ }^{3}$. The correspondence appears to be exact: Pseudo-Primasius is surely nothing else than the new and standard commentary on the completed Pauline epistles evolved out of Pelagius and Chrysostom by Cassiodorus and his monks of Vivarium. The hypothesis seems to me to be at any rate worthy of further consideration.

C. H. Turner.
1 Pelagius in Irland, p. 122.
$\therefore b$ pp. $183-195$
เb. p. 202 . 